NBER WORKING PAPER SERIES

\title{
DISTANCE, SKILL DEEPENING AND DEVELOPMENT: WILL PERIPHERAL COUNTRIES EVER GET RICH?
}

\author{
Stephen Redding \\ Peter K. Schott \\ Working Paper 9447 \\ http://www.nber.org/papers/w9447 \\ NATIONAL BUREAU OF ECONOMIC RESEARCH \\ 1050 Massachusetts Avenue \\ Cambridge, MA 02138 \\ January 2003
}

We thank Joshua Aizenman, Mary Amiti, Andrew Bernard, Sebastian Edwards, David Hummels, Jon Temple, Henry Thompson, and Tony Venables for valuable comments. We are also grateful for feedback received during seminars at the EIIT9, the London School of Economics and the NBER IASE conference in Monterrey Mexico. Marco Schonborn and Martin Stewart provided able research assistance. The views expressed herein are those of the authors and not necessarily those of the National Bureau of Economic Research.

(C)2003 by Stephen Redding and Peter K. Schott. All rights reserved. Short sections of text not to exceed two paragraphs, may be quoted without explicit permission provided that full credit including notice, is given to the source. 
Distance, Skill Deepening and Development: Will Peripheral Countries Ever Get Rich? Stephen Redding and Peter K. Schott NBER Working Paper No. 9447

January 2003

JEL No. F12, F14, O10

\section{$\underline{\text { ABSTRACT }}$}

This paper models the relationship between countries' distance from global economic activity, endogenous investments in education, and economic development. Firms in remote locations pay greater trade costs on both exports and intermediate imports, reducing the amount of value added left to remunerate domestic factors of production. If skill-intensive sectors have higher trade costs, more pervasive input-output linkages, or stronger increasing returns to scale, we show theoretically that remoteness depresses the skill premium and therefore incentives for human capital accumulation. Empirically, we exploit structural relationships from the model to demonstrate that countries with lower market access have lower levels of educational attainment. We also show that the world's most peripheral countries are becoming increasingly remote over time.

\author{
Stephen Redding \\ London School of Economics \\ Houghton Street, London \\ WC2A 2AE \\ United Kingdom \\ s.j.redding@1se.ac.uk
}

\author{
Peter K. Schott \\ Yale School of Management \\ 135 Prospect Street \\ New Haven, CT 06520-8200 \\ and NBER \\ peter.schott@yale.edu
}




\section{Introduction}

Why some nations are rich and others are poor is perhaps one of the oldest and most fundamental questions in economics. In 1996, the per capita income of the country at the 90th percentile of the world income distribution was more than 30 times higher than the country at the 10th percentile. The persistence of such differences is surprising in light of the increasing integration of goods and financial markets in the post-war period. Economists have pointed to a number of factors which may have prevented these income differences from being arbitraged away, including institutional ineffectiveness, sluggish technology diffusion and endowment disadvantages. ${ }^{1}$

A more recent line of research has highlighted the potential importance of trade costs in reducing per capita income. ${ }^{2}$ These trade costs include not only the expense of physically moving products between locations but also all information, monitoring and policy (e.g. tariff) costs associated with transacting at a distance. Because firms located in remote locations pay greater trade costs on both their sales to final markets and their purchases of imported intermediate inputs, they have less value added available to remunerate domestic factors of production.

In this paper we focus on an additional penalty of remoteness. We demonstrate that being located on the economic periphery can reduce the return to skill, thereby reducing incentives for investment in human capital accumulation. This penalty magnifies the effect that economic geography can have on cross-country per capita income; increasing a country's relative trade costs not only reduces contemporaneous factor rewards, but also lowers gross domestic product by suppressing human capital accumulation and

\footnotetext{
${ }^{1}$ Engerman and Sokoloff (1997) and Leamer et al. (1999), for example, analyse the effect of institutions and resource endowments on educational attainment in Latin America. Studies examining the links between human capital, development, and growth include Benhabib and Spiegel (1994), Bils and Klenow (2000), Eicher and Garcia-Penalosa (2001), Galor and Mountford (2001), Lucas (1988), and Mankiw et al. (1992).

${ }^{2}$ See, in particular, Hanson (1998) and Redding and Venables (2001). For earlier, more informal analyses of location and per capita income, see Hummels (1995) and Leamer (1997). This paper focuses on economic geography (the location of economic agents relative to oneanother in space) rather than physical geography (e.g climate). For a discussion of the latter, see for example Gallup et al (1998).
} 
decreasing the supply of high-income skilled workers. ${ }^{3}$ This result emerges from an extension of the standard two sector (agriculture and manufacturing) Fujita et al (1999) economic geography model to allow unskilled individuals to endogenously choose whether to invest in education. We believe the role of economic geography in explaining persistent low levels of educational attainment in developing countries to be important and largely neglected in the existing literature.

The paper reports three main theoretical results. First, we show that countries located further from global economic activity have a lower skill premium if manufactured goods are relatively skill intensive and face relatively large trade costs. The intuition for this result can be conveyed via the well-known Stolper-Samuelson theorem: increased remoteness has the same affect as a reduction in the relative price of the manufactured good. Because manufacturing is relatively skill intense, the relative wage of skilled workers - and the incentive to educate - falls.

Second, we demonstrate that this result is robust to more general assumptions regarding trade costs, in particular the assumption that trade costs are higher for agriculture than for manufacturing. ${ }^{4}$ The result generalizes because of input-output linkages and increasing returns to scale in skill intensive manufacturing. Input-ouput linkages are important because trade costs must be paid on both imports and exports, with the result that even relatively small trade costs can be magnified into a relatively large share of value added. Increasing returns to scale, on the other hand, emphasizes the importance of proximity to large markets. Firms that are remote from large markets have to charge a lower price net of trade costs in order to export sufficient quantity to cover fixed costs. As a result, the equilibrium skill premium depends upon both physical remoteness (i.e. bilateral trade costs) and economic remoteness (i.e. the spatial distribution of economic activity).

Third, we show how our model can be used to formalize the role of a number of other determinants of human capital investment, including agri-

\footnotetext{
${ }^{3} \mathrm{~A}$ wide range of empirical studies for developed and developing countries provide evidence that skilled or educated workers receive higher wages (see Psacharopoulos 1994 for a survey of this literature).

${ }^{4}$ Bernard et al (2002), for example, show that while US tariffs are higher for skill intensive manufactures (e.g. electronics), freight and insurance costs are higher for bulk commodities (e.g. Food).
} 
cultural productivity and technology. We demonstrate that higher agricultural productivity (or, more generally, an abundance of natural resources) hinders manufacturing development and reduces incentives to invest in human capital. We also show that a transfer of manufacturing technology from developed to developing countries not only raises output per capita directly but also has a positive indirect effect through induced human capital accumulation. In general, the indirect effect will not be internalized by private sector agents, and the existence of this pecuniary externality provides a potential rationale for policies designed to accelerate technology transfer.

While the main focus of the paper is theoretical, we exploit structural relationships from the model to provide empirical evidence that countries located far from centers of world economic activity are characterized by relatively low levels of educational attainment. We also provide evidence that the world's most peripheral countries are becoming relatively more remote from global economic activity over time.

The paper proceeds as follows. Sections 2 and 3 outline the theoretical model and explore the relationship between remoteness and equilibrium investments in skill. Section 4 generalizes the analysis to allow for a more general specification of trade costs. Section 5 examines the role of other determinants of human capital investments. Sections 6 and 7 use the structure of the model to derive empirical measures of market access and examine the link between market access and educational attainment. Section 8 concludes.

\section{Theoretical Model}

This paper builds upon existing theoretical research on new economic geography as synthesized in Fujita et al (1999). ${ }^{5}$ We extend the standard economic geography model by introducing endogenous human capital accumulation. The analysis emphasizes the importance of the interplay between increasing returns to scale, transport costs, input-output linkages,

\footnotetext{
${ }^{5}$ See also Krugman (1991), Krugman and Venables (1990, 1995), and Venables (1996). In the interests of tractability, much of this literature has assumed a single factor of production, labor. Recent research by Amiti (2001) and Strauss-Kahn (2001) has introduced considerations of Heckscher-Ohlin trade theory into this framework by endowing countries with exogenous quantities of multiple factors of production.
} 
and human capital investments. ${ }^{6}$ We derive predictions for the relationship between remoteness, international trade, human capital investment, and levels of per capita income.

\subsection{Preferences and Endowments}

The world consists of $i \in\{1, \ldots, R\}$ countries. Each country is endowed with a mass of $\bar{L}_{i}$ consumers. Consumers have one unit of labour which is supplied inelastically with zero disutility. This unit of labour begins in an unskilled state, but individuals choose endogenously whether or not to invest in becoming skilled. Consumer preferences are identical and homothetic, and are defined over consumption of a homogenous agricultural good and a variety of differentiated manufacturing goods. For simplicity, the utility function is assumed to take the Cobb-Douglas form,

$$
U_{j}=A_{j}^{(1-\mu)} M_{j}^{\mu}, \quad 0<\mu<1
$$

where $A$ denotes consumption of the homogeneous agricultural good and $M$ corresponds to a consumption index of differentiated varieties. Going forward, we use $j$ to denote a country that is demanding or importing a good and $i$ to denote a country that is producing or exporting a good. The consumption index of differentiated varieties takes the form

$$
M_{j}=\left[\sum_{i=1}^{R} \int_{0}^{n_{i}} m_{i j}^{C}(z)^{(\sigma-1) / \sigma} d z\right]^{\sigma /(\sigma-1)}=\left[\sum_{i=1}^{R} n_{i}\left(m_{i j}^{C}\right)^{(\sigma-1) / \sigma}\right]^{\sigma /(\sigma-1)}
$$

where $\sigma>1$ is the elasticity of substitution between manufacturing varieties and the second equation exploits the fact that, in the equilibrium established below, all products produced in a country $i$ are demanded by country $j$ in the same quantity. As a result, we dispense with the index $z$ and rewrite the integral as a product. $n_{i}$ denotes the number of varieties produced in country $i$ and $m_{i j}^{C}$ denotes the amount of each variety produced in country $i$ for final consumption in country $j$.

\footnotetext{
${ }^{6}$ In terms of Marshall (1920)'s three forces of agglomeration (a pooled market for specialized skills, input-output linkages, and knowledge spillovers), our analysis focuses on input-output linkages. For a model of agglomeration emphasizing search frictions in the labour market, see Amiti and Pissarides (2002), while Mori and Turrini (2002) emphasize complementarities between product variety, product quality, and skills.
} 
Dual to the manufacturing goods consumption index $\left(M_{j}\right)$ is a manufacturing goods price index $\left(G_{j}\right)$ defined over the prices of individual varieties produced in $i$ and sold in $j$ (i.e. $p_{i j}^{M}$ ),

$$
G_{j}=\left[\sum_{i=1}^{R} \int_{0}^{n_{i}} p_{i j}^{M}(z)^{1-\sigma} d z\right]^{1 /(1-\sigma)}=\left[\sum_{i=1}^{R} n_{i}\left(p_{i j}^{M}\right)^{1-\sigma}\right]^{1 /(1-\sigma)},
$$

where the second equation makes use of the symmetry in equilibrium prices.

\subsection{Production Technologies}

The homogenous agricultural good is produced under conditions of perfect competition with the following constant returns to scale technology,

$$
Y_{i}=\theta_{i}^{Y}\left(S_{i}^{Y}\right)^{\phi}\left(L_{i}^{Y}\right)^{1-\phi}, \quad 0<\phi<1
$$

where $Y_{i}$ denotes output of the agricultural good; $L_{i}^{Y}$ denotes the amount of unskilled labour allocated to this sector; $S_{i}^{Y}$ denotes the amount of skilled labour allocation; and $\theta_{i}^{Y}$ indexes agricultural productivity. ${ }^{7}$

To facilitate comparison of our results with the standard economic geography model without endogenous human capital investments, we begin with the conventional assumption that the homogenous agricultural good is traded at no cost. We relax this assumption below to explore further how relative trade costs across sectors influence incentives for human capital accumulation. $^{8}$

Varieties of traded goods are produced with an increasing returns to scale technology using a composite of primary factors of production (skilled and unskilled labour) and the output of all manufacturing goods (intermediate inputs). The representative country $i$ firm thus faces the following cost function,

$$
\Gamma_{i}=\left(w_{i}^{S}\right)^{\alpha}\left(w_{i}^{U}\right)^{\beta} G_{i}^{(1-\alpha-\beta)} c_{i}\left[F+x_{i}\right]
$$

\footnotetext{
${ }^{7}$ While not explicitly modelled here, $\theta_{i}^{Y}$ may be thought of as capturing the effects of endowments of land, other factors of production, and the nature of land holdings on agricultural productivity. Introducing these other factors of production more explicitly merely complicates the analysis without adding any insight.

${ }^{8}$ Our focus is on endogenous human capital investments. Davis (1999) examines how agricultural trade costs affect the 'home market effect', while Venables and Limao (2002) consider the relationship between relative trade costs across sectors and industrial structure.
} 
where $c_{i}$ denotes a constant marginal input requirement; $c_{i} F$ is a fixed input requirement; and $x_{i}=\sum_{j=1}^{R} x_{i j}$ is the total output of the firm produced for all markets. We assume that the composite of primary factors of production and intermediate inputs takes the Cobb-Douglas form, where $w_{i}^{S}$ is the wage of skilled workers (with input share $\alpha$ ), $w_{i}^{U}$ is the wage of unskilled workers (with input share $\beta$ ), and $G_{i}$ is the price index for manufacturing goods from equation (3) (with input share $(1-\alpha-\beta)$ ). The parameter $c_{i}$ corresponds to an index of technological efficiency that may potentially vary across countries.

We assume trade costs take the iceberg form. ${ }^{9}$ In order for one unit of a traded good to arrive in location $j$ from location $i, T_{i j}^{M}>1$ units must be shipped. Thus, when $T_{i j}^{M}=1$ trade is costless, and $T_{i j}^{M}-1$ measures the proportion of output lost in shipping from $i$ to $j$. We assume the parameter $T_{i j}^{M}$ captures all trade costs between locations $i$ and $j$, including physical transportation costs, information, communication, and monitoring costs, tariff barriers and non-tariff barriers. ${ }^{10}$

\subsection{Human Capital Investment}

An individual $z$ in country $i$ is endowed with one unit of unskilled labour, which can be converted into a unit of skilled labour by incurring a fixed education cost of $\Omega_{i}(z)$ units of unskilled labour. Denominating the education cost in terms of unskilled labour captures the idea that real resources are used in the process of becoming skilled. As a result, the cost of education is proportional to the unskilled wage, reflecting the higher opportunity cost of the real resources used in countries with a higher unskilled wage (see also Eicher and Garcia-Penalosa 2001).

The amount of unskilled labour used in becoming skilled depends on two components: $\Omega_{i}(z)=h_{i} / a(z)$. First, the parameter $h_{i}$ captures the effect of all aspects of the institutional environment and of government policies

\footnotetext{
${ }^{9}$ We use iceberg trade costs for tractability. All we require is that remote locations face greater trade costs.

${ }^{10}$ Hummels (1999) and Limao and Venables (2001) provide evidence on the importance of transport costs and the role of geography in determining their magnitude. See Leamer and Storper (2001) and Venables (2001) for a discussion of the continuing and sometimes increasing importance of location following the introduction of new information and communication technologies such as e-mail and the internet.
} 
that influence individuals' private costs of education. These include, for example, the extent of public versus private provision of education, compulsory schooling laws and other government regulations, as well as explicit subsidies and grants. The parameter $h_{i}$ is an inverse measure of the extent of public provision, so that higher values of $h_{i}$ correspond to a higher private cost of education.

Second, an individual's education cost depends on their ability $a(z)$, and we assume that high ability individuals face lower education costs. This captures the idea that high-ability individuals have to work less hard in order to attain a given level of education or are able to complete their education in a shorter period of time. Although we have chosen here to make the costs of education a function of ability, one could equivalently assume that the cost of education is the same for all individuals but that the rate of return varies with ability. ${ }^{11}$

We assume that there are upper and lower bounds to ability determined by human biology and that an individual's ability is drawn from a distribution over the interval $[\underline{a}, \bar{a}]$. The probability density function of ability is denoted by $\lambda(a)$, so that the mass of individuals in country $i$ with a particular level of ability $a^{\prime}$ is $\lambda\left(a^{\prime}\right) \bar{L}_{i}$. We assume the probability density function of ability is determined by human biology and is therefore the same in all countries.

An individual $z$ in country $i$ will choose to become educated if the wage differential between skilled and unskilled workers exceeds education costs,

$$
w_{i}^{S}-w_{i}^{U} \geq \frac{h_{i}}{a(z)} w_{i}^{U} .
$$

We assume that the cumulative distribution function of ability $\Lambda(a)=$ $\int_{\underline{a}}^{a} \lambda(a) d a$ is continuous and monotonically increasing in ability. That is, as we consider successively higher and higher levels of ability, there will be fewer individuals more able than this level. The analysis is compatible

\footnotetext{
${ }^{11}$ In this alternative specification, the wage $w_{i}^{S}$ in firms' cost function is the wage per ability-adjusted (quality-adjusted) unit of skilled labour. An individual $z$ of ability $a(z)$ receives an actual wage of $a(z) w_{i}^{S}$. In the alternative formulation, the ability-adjusted skilled wage is the same for all individuals, but actual wages vary with individual ability. All of the paper's results are robust to considering the alternative specification. It is only necessary to slightly modify the condition for an individual to become skilled in equation (6) to: $a(z) w_{i}^{S}-w_{i}^{U} \geq h_{i} w_{i}^{U}$.
} 
with a wide range of probability density functions for ability. A particularly tractable case is where ability is uniformly distributed over the interval $[\underline{a}, \bar{a}]$, in which case $\lambda(a)=1 /[\bar{a}-\underline{a}]$.

\subsection{General Equilibrium}

\subsubsection{Consumer Equilibrium}

Consumers maximize utility subject to their budget constraint. The first-order conditions imply the following demand-side relationship between the relative price and relative consumption of the two goods,

$$
\frac{p_{j}^{Y}}{G_{j}}=\frac{1-\mu}{\mu} \frac{M_{j}}{A_{j}},
$$

where $p_{j}^{Y}$ is the price of the agricultural good and $G_{j}$ is the manufacturing goods price index from above. Equation (7) determines country $j$ 's consumption of all manufacturing goods (of the consumption index $M_{j}$ ). Final consumption demand for individual varieties produced in $i$ may be derived by applying Shepherd's Lemma to the manufacturing price index $\left(G_{j}\right)$,

$$
m_{i j}^{C}=\left(p_{i j}^{M}\right)^{-\sigma} E_{j}^{C} G_{j}^{\sigma-1},
$$

where $E_{j}^{C}$ denotes total consumer expenditure on manufacturing goods in country $j$.

\subsection{Equilibrium Supply of Skills}

The individual's education decision compares the wage differential between skilled and unskilled workers with the costs of education. Equation (6) implicitly defines a critical value for ability $a_{i}^{*}$ such that all individuals with levels of ability $a(z) \geq a_{i}^{*}\left(z^{*}\right)$ choose to become skilled. From above, this critical value for ability is,

$$
a_{i}^{*}=\frac{h_{i}}{\left(w_{i}^{S} / w_{i}^{U}-1\right)} .
$$

The marginal individual with the critical level of ability $a_{i}^{*}$ is indifferent between becoming skilled and remaining unskilled, and equation (9) is therefore termed the skill indifference condition $(\mathbf{S})$. 
Proposition 1 The equilibrium critical level of ability $a_{i}^{*}$ above which individuals become skilled is monotonically decreasing in the relative skilled wage $\left(w_{i}^{S} / w_{i}^{U}\right)$ and monotonically increasing in the cost of education parameter $\left(h_{i}\right)$

Proof. Proposition 1 follows immediately from the skill indifference condition $(\boldsymbol{S})$.

Intuitively, as the relative wage of skilled workers $\left(w_{i}^{S} / w_{i}^{U}\right)$ increases, it becomes profitable for individuals of lower ability to invest in education. As the critical level of ability $a_{i}^{*}$ falls, the equilibrium number of skilled workers increases and the equilibrium number of unskilled workers decreases. The equilibrium masses of skilled and unskilled workers are,

$$
\begin{gathered}
S_{i}=\int_{a_{i}^{*}}^{\bar{a}} \lambda(a) \bar{L}_{i} d a \\
L_{i}=\int_{\underline{a}}^{a_{i}^{*}} \lambda(a) \bar{L}_{i} d a-\int_{a_{i}^{*}}^{\bar{a}} \frac{h}{a} \lambda(a) \bar{L}_{i} d a \\
S_{i}+L_{i}+\int_{a_{i}^{*}}^{\bar{a}} \frac{h}{a} \lambda(a) \bar{L}_{i} d a=\bar{L}_{i}
\end{gathered}
$$

Figure 1 graphs the relationship between the relative wage and the critical level of ability above which individuals become skilled (the righthand side of equation (9)).

\subsection{Producer Equilibrium}

In the agricultural sector, profit maximization and constant returns to scale imply that price equals unit costs of production if the agricultural good is produced,

$$
p_{i}^{Y}=1=\frac{1}{\theta_{i}^{Y}}\left(w_{i}^{S}\right)^{\phi}\left(w_{i}^{U}\right)^{1-\phi},
$$

where we choose the agricultural good for the numeraire and hence $p_{i}^{Y}=1$ for all $i$. In the manufacturing sector, the representative country $i$ firm maximizes the following profit function,

$$
\pi_{i}=\sum_{j=1}^{R} \frac{p_{i j}^{M} x_{i j}}{T_{i j}^{M}}-\left(w_{i}^{S}\right)^{\alpha}\left(w_{i}^{U}\right)^{\beta} G_{i}^{(1-\alpha-\beta)} c_{i}\left[F+x_{i}\right] .
$$


The first-order conditions for profit-maximization yield the standard result that equilibrium prices are a constant mark-up over marginal cost,

$$
p_{i}^{M}=\left(\frac{\sigma}{\sigma-1}\right)\left(w_{i}^{S}\right)^{\alpha}\left(w_{i}^{U}\right)^{\beta} G_{i}^{(1-\alpha-\beta)} c_{i}
$$

where $p_{i}^{M}=p_{i j}^{M} / T_{i j}^{M}$ is the 'free on board' or 'customs' price charged by the firm prior to trade costs. Substituting this pricing rule into equation (14), we obtain the following expression for the equilibrium profit function,

$$
\pi_{i}=\left(\frac{p_{i}^{M}}{\sigma}\right)\left[x_{i}-(\sigma-1) F\right] .
$$

In order to break even in a monopolistically competitive equilibrium, the firm's output must equal a constant: $\bar{x}=(\sigma-1) F$. The price needed to sell this many units is determined by the firm's demand function, where demand consists of the sum of final consumption and intermediate demand across all markets. A firm in country $i$ will therefore sell the quantity $\bar{x}$ when it charges a price, ${ }^{12}$

$$
\left(p_{i}^{M}\right)^{\sigma}=\left(\frac{1}{\bar{x}}\right) \sum_{j=1}^{R} E_{j} G_{j}^{\sigma-1}\left(T_{i j}^{M}\right)^{1-\sigma},
$$

where $E_{j}=E_{j}^{C}+E_{j}^{I}$ denotes total country $j$ expenditure (final consumption and intermediate) on manufacturing goods.

Combining the expression in equation (17) with the fact that, in equilibrium, prices are a constant mark-up over marginal cost, we obtain the following zero-profit condition,

$$
\text { (W) }\left(\frac{\sigma}{\sigma-1}\left(w_{i}^{S}\right)^{\alpha}\left(w_{i}^{U}\right)^{\beta} G_{i}^{(1-\alpha-\beta)} c_{i}\right)^{\sigma}=\left(\frac{1}{\bar{x}}\right) \sum_{j=1}^{R} E_{j} G_{j}^{\sigma-1}\left(T_{i j}^{M}\right)^{1-\sigma} .
$$

This relationship is termed the wage equation $(\mathbf{W})$. It pins down the maximum wages of skilled and unskilled workers that a firm in country $i$ can afford to pay, given demand for its products (as captured in the summation on the right-hand side of the equation), and given the cost of intermediate inputs (as captured in the manufacturing price index on the left-hand side of the equation).

\footnotetext{
${ }^{12}$ The transport cost term $\left(T_{i j}\right)$ enters with exponent $1-\sigma$ and not $\sigma$ because total shipments to market $j$ are $T_{i j}$ times quantities consumed.
} 


\subsubsection{Market Clearing Conditions}

Factors are relatively immobile internationally, and we therefore make the standard trade theory assumption of factor mobility across sectors within a country and immobility across countries. General equilibrium requires that each country's labour market clears,

$$
\begin{aligned}
S_{i}^{Y}+S_{i}^{M} & =S_{i} \\
L_{i}^{Y}+L_{i}^{M} & =L_{i}
\end{aligned}
$$

where $\left\{S_{i}^{M}, L_{i}^{M}\right\}$ and $\left\{S_{i}^{Y}, L_{i}^{Y}\right\}$ denote skilled and unskilled employment in the manufacturing and agricultural sectors respectively. The total supplies of skilled and unskilled labour $\left\{S_{i}, L_{i}\right\}$ are determined according to equations (10) and (11) above.

In equilibrium, we also require goods markets to clear at the world level, for manufacturing varieties and the homogeneous agricultural good.

\section{Geography and Skill Deepening}

The full general equilibrium of the model combines consumer optimization, education optimization, and producer optimization with the market clearing conditions to solve for equilibrium prices, equilibrium expenditures, and the equilibrium location of production.

In this section, we use structural equations of the model to characterize the nature of the relationship between location and incentives to invest in skills that must hold in general equilibrium. We follow Redding and Venables (2001) in using the model to derive theory-consistent measures of a country's location relative to its markets and sources of supply. We then go on to demonstrate how market access and supplier access influence incentives to invest in human capital acquisition.

We begin by combining final consumption demand (from equation (8)) and intermediate demand to obtain an expression for bilateral trade flows between countries $i$ and $j$. Expressing this relationship in aggregate value terms, yields,

$$
n_{i} p_{i} x_{i j}=n_{i} p_{i}^{1-\sigma}\left(T_{i j}^{M}\right)^{1-\sigma} E_{j} G_{j}^{\sigma-1} .
$$

In this gravity equation (the trade equation $(\mathbf{T})$ ), bilateral exports depend

on three sets of considerations. First, on a measure of demand in the 
importing country $j$ termed market capacity $\left(m_{j} \equiv E_{j} G_{j}^{\sigma-1}\right)$ and comprised of total expenditure on manufacturing goods in market $j\left(E_{j}\right)$ as well as the number of competing firms and the prices they charge as summarized in the manufacturing price index $\left(G_{j}\right)$. Second, on a measure of supply potential in the exporting country $i$ termed supply capacity $\left(s_{i} \equiv n_{i} p_{i}^{1-\sigma}\right)$ and comprised of the number of manufacturing firms $\left(n_{i}\right)$ together with the prices they charge $\left(p_{i}\right)$. Third, on bilateral trade costs $\left(T_{i j}^{M}\right)^{1-\sigma}$.

For each exporter $i$, we may sum market capacities in the importers it serves, weighting by bilateral trade costs. This yields a measure of the country's overall access to markets - market access $\left(M A_{i}\right)$,

$$
M A_{i} \equiv \sum_{j=1}^{R}\left(T_{i j}^{M}\right)^{1-\sigma} E_{j} G_{j}^{\sigma-1}=\sum_{j=1}^{R}\left(T_{i j}^{M}\right)^{1-\sigma} m_{j} .
$$

Similarly, for each importer $j$, we may sum supply capacities in the exporters that it receives goods from, weighting by bilateral trade costs. This yields a measure of the country's overall access to sources of supply - supplier access $\left(S A_{j}\right)$,

$$
S A_{j} \equiv \sum_{i=1}^{R}\left(T_{i j}^{M}\right)^{1-\sigma} n_{i} p_{i}^{1-\sigma}=\sum_{i=1}^{R}\left(T_{i j}^{M}\right)^{1-\sigma} s_{i} .
$$

From the trade equation $(\mathbf{T})$, market and supplier access may be constructed from information on bilateral trade flows. We now show how the wage equation ( $\mathbf{W})$, which pins down the maximum wages of skilled and unskilled workers that firms in each location can afford to pay, may be written as a function of market and supplier access. Taking the manufacturing price index over to the right-hand side of $(\mathbf{W})$ and using the definition in equation (22), we have,

$$
\left(w_{i}^{S}\right)^{\alpha}\left(w_{i}^{U}\right)^{\beta}=\xi \frac{1}{c_{i}}\left(M A_{i}\right)^{\frac{1}{\sigma}} G_{i}^{(\alpha+\beta-1)},
$$

where $\xi$ absorbs earlier constants. Now note from equations (3) and (23) that the manufacturing price index $\left(G_{i}\right)$ may be written as a function of a country's supplier access alone,

$$
\text { (P) } \quad G_{i}=\left[S A_{i}\right]^{\frac{1}{1-\sigma}} \text {. }
$$


Combining the expression for the price index $(\mathbf{P})$ with equation $(24)$, the maximum skilled and unskilled wages that a firm in location $i$ can afford to pay can be written as,

$$
\left(\mathbf{W}^{\prime}\right) \quad\left(w_{i}^{S}\right)^{\alpha}\left(w_{i}^{U}\right)^{\beta}=\xi \frac{1}{c_{i}}\left(M A_{i}\right)^{\frac{1}{\sigma}}\left(S A_{i}\right)^{\frac{(1-\alpha-\beta)}{(\sigma-1)}} .
$$

Intuitively, countries whose locations provide easy access to supplies of manufacturing goods (a high value of $S A_{i}$ ) are characterized by low values of the manufacturing price index. This itself reduces unit costs of production and increases the maximum wages that manufacturing firms in those locations can afford to pay. If a country's location also provides easy access to markets for manufacturing goods (a high value of $M A_{i}$ ), this increases the 'free on board' price that manufacturing firms can charge for their products while still selling enough output to cover the fixed costs of production, thereby again increasing the maximum wages that the firms can afford to pay.

Consider a country that is incompletely specialized in agriculture and manufacturing. We establish below the conditions under which this occurs. ${ }^{13}$ The zero profit conditions in agriculture (13) and manufacturing (26) together implicitly define the equilibrium wages of skilled and unskilled workers. Manipulating these zero profit conditions and combining them with the skill indifference condition $(\mathbf{S})$, we are able to completely characterize the equilibrium relationship between geographical location and endogenous human capital investments. Taking logarithms and totally differentiating each zero profit condition, we have,

$$
0=\phi \frac{d w_{i}^{S}}{w_{i}^{S}}+(1-\phi) \frac{d w_{i}^{U}}{w_{i}^{U}}
$$

\footnotetext{
${ }^{13}$ As in the standard economic geography model, incomplete specialization will occur for relatively high values of trade costs and, empirically, we find that countries produce both agriculture and manufacturing. It is straightforward to also examine the complete specialization case. For a country completely specialized in manufacturing, the relative wage will be determined by combining the relative supply of skilled workers from Proposition 1 with a relative demand relationship derived from the manufacturing wage equation. This relative demand relationship is a function of market and supplier access, and hence geographical location again plays an important role in determining relative factor prices.
} 


$$
\alpha \frac{d w_{i}^{S}}{w_{i}^{S}}+\beta \frac{d w_{i}^{U}}{w_{i}^{U}}=\frac{1}{\sigma} \frac{d M A_{i}}{M A_{i}}+\frac{(1-\alpha-\beta)}{(\sigma-1)} \frac{d S A_{i}}{S A_{i}}
$$

Proposition 2 Suppose a country becomes more remote in the sense that equilibrium market and supplier access fall $\left(d M A_{i} / M A_{i}=d S A_{i} / S A_{i}=\right.$ $-\gamma<0)$. If manufacturing is skill-intensive relative to agriculture and the country remains incompletely specialized, the new equilibrium must be characterized by a lower relative wage of skilled workers.

Proof. See Appendix.

Intuitively, a fall in market and supplier access in the manufacturing zero profit condition acts exactly like a fall in the price of the skill-intensive good in the Stolper-Samuelson Theorem of Heckscher-Ohlin trade theory. A fall in market and supplier access leads to a violation of the manufacturing zero profit condition at initial equilibrium factor prices and results in a decline in the size of the manufacturing sector. The decline in manufacturing releases relatively more skilled labour than is demanded in agriculture at initial equilibrium relative factor prices. Hence, at the new equilibrium, the nominal skilled wage is lower, the nominal unskilled wage is higher (so that the agricultural zero profit condition continues to be satisfied), and these together imply that the relative wage of skilled workers is lower.

A lower relative wage of skilled workers unambiguously reduces the incentive to invest in skills. Hence, as a country's equilibrium values of market and supplier access fall, the number of skilled workers falls and the number of unskilled workers rises.

Proposition 3 Suppose a country becomes more remote in the sense that equilibrium market and supplier access fall ( $d M A_{i} / M A_{i}=d S A_{i} / S A_{i}=$ $-\gamma<0)$. If manufacturing is skill-intensive relative to agriculture and the country remains incompletely specialized, the new equilibrium must be characterized by:

(a) a higher critical level of ability $a_{i}^{*}$ above which individuals become skilled (b) a reduced supply of skilled workers and an increased supply of unskilled workers

Proof. See Appendix.

Equilibrium relative wages and employment in the two sectors for given levels of market and supplier access are shown graphically in Figure 2. This 
is the direct analogue of the isoprice line representation of equilibrium in the Heckscher-Ohlin trade model (the dual of the Lerner diagram). The more steeply-sloped curve is the unit cost function in agriculture, which must equal price in an equilibrium where agriculture is produced. The more shallow-sloped curve is the marginal cost function in manufacturing $\left(b_{i}=\right.$ $\left.\left(w_{i}^{S}\right)\left(w_{i}^{U}\right) G_{i}^{(1-\alpha-\beta)} c_{i}\right)$, which is drawn in skilled wage-unskilled wage space for a given level of market and supplier access. The level of supplier access pins down the value of the manufacturing price index $\left(G_{i}=\left[S A_{i}\right]^{\frac{1}{1-\sigma}}\right)$. The manufacturing wage equation ( $\mathbf{W}^{\prime}$ ) implies that, in an equilibrium where manufacturing goods are produced, marginal costs are proportional to market access $\left(b_{i}=\xi\left(M A_{i}\right)^{\frac{1}{\sigma}}\right)$.

A reduction in market and supplier access corresponds to an inward shift in the manufacturing isoprice line (less value added is available to remunerate the factors of production). From Figure 2, the new equilibrium must be characterized by a lower skilled wage and higher unskilled wage. The manufacturing production technology implies that marginal and average relative unit factor input requirements are the same. Hence, the slope of each isoprice line corresponds to relative employment of skilled and unskilled labour by a representative firm in that sector. In order for both manufacturing and agriculture to be produced in equilibrium, we require that, at the equilibrium relative factor prices $\left(\hat{w}_{i}^{S}, \hat{w}_{i}^{U}\right)$, the slope of a line indicating the endogenous relative supply of skilled and unskilled workers $\left(S_{i}, L_{i}\right)$ lies in between the tangents to the two isoprice lines.

In the full general equilibrium of the model, market and supplier access are endogenously determined by the distribution of production and expenditure across locations. Propositions 2 and 3 characterize relationships that hold in the full general equilibrium. They exploit the equilibrium structure of production and the supply of skills to characterize the relationship between market access, supplier access, and human capital investments when countries are incompletely specialized. ${ }^{14}$ In our empirical work, we use the trade equation $(\mathbf{T})$ to measure market and supplier access from bilateral trade data. We take as given the location of production and expenditure,

\footnotetext{
${ }^{14}$ Again, note the analogy with the Stolper-Samuelson Theorem. In general, relative goods prices are endogenously determined. The Stolper-Samuelson Theorem exploits the equilibrium structure of production to derive a relationship between relative goods and relative factor prices when countries are incompletely specialized.
} 
as revealed by bilateral trade, and examine to what extent cross-country investments in human capital are consistent with the equilibrium relationship predicted by the model.

To keep the analysis as clean as possible and to facilitate comparison with the standard economic geography model, we have so far assumed that the agricultural good is freely traded. In the next Section, we relax this assumption.

\section{Equilibrium with Trade Costs in Manufacturing and Agriculture}

To introduce agricultural trade costs in as tractable way as possible, we modify consumers' utility functions slightly. Specifically, we assume that each country produces a single differentiated agricultural good. ${ }^{15}$ These differentiated goods enter a consumption index $A_{j}$ in equation (1) that takes the Dixit-Stiglitz form,

$$
A_{j}=\left[\sum_{i=1}^{R} A_{i j}^{(\sigma-1) / \sigma}\right]^{\sigma /(\sigma-1)}, \quad \sigma>1 .
$$

The differentiation of goods across countries may be interpreted in two ways, which for our purposes are equivalent. First, there are a number of different agricultural goods (e.g. wheat, corn, barley, maize) which are imperfect substitutes for one another, and each country completely specializes in a different agricultural good due to Ricardian differences in technology or unmodelled variation in land endowments (as in Davis 1997; see also Deardorff 1998 and Krugman and Venables 2001). Second, there is Armington differentiation by country of origin. The first is the more plausible interpretation and the one taken here.

In order for one unit of an agricultural good to arrive in location $j$ from location $i$, we assume that $T_{i j}^{A}>1$ units must be shipped, so that $T_{i j}^{A}-1$ is a

\footnotetext{
${ }^{15}$ It is possible to analyze the role of agricultural trade costs while retaining the assumption that agricultural goods are homogenous. This complicates the analysis because, with an homogenous product and trade costs, exporters of agriculture will not generally export to all locations and importers will not generally import from all locations (see for example Venables and Limao 2002). As discussed further below, one interpretation of the specification here is that countries are specialized in different agricultural goods which are imperfect substitutes for oneanother.
} 
measure of agricultural trade costs. With perfect competition and constant returns to scale, the free on board $(f o b)$ price of agricultural goods in each location $i$ will equal average cost, while the cost inclusive of freight price (cif) charged in an importing location $j$ will be a mark-up over average cost with the size of the mark-up determined by bilateral trade costs,

$$
\frac{p_{i j}^{Y}}{T_{i j}^{A}}=p_{i}^{Y}=\frac{1}{\theta_{i}^{Y}}\left(w_{i}^{S}\right)^{\phi}\left(w_{i}^{U}\right)^{1-\phi},
$$

and we choose the cif price of country $i$ 's agricultural good in one location (for example, $j=1$ ) as the numeraire (so that $p_{i 1}^{Y}=1$ and $p_{i}^{Y}=1 / T_{i 1}^{A}$ ).

The manufacturing zero profit condition (26) continues to depend on market and supplier access, while agricultural trade costs $\left(T_{i j}^{A}\right)$ now enter directly into the agricultural zero profit condition (30). To examine the effects of increased remoteness, we again totally differentiate the two zero profit conditions, assuming that a country remains incompletely specialized in agriculture and manufacturing,

$$
\begin{aligned}
& -\frac{d T_{i 1}^{A}}{T_{i 1}^{A}}=\phi \frac{d w_{i}^{S}}{w_{i}^{S}}+(1-\phi) \frac{d w_{i}^{U}}{w_{i}^{U}} \\
& \alpha \frac{d w_{i}^{S}}{w_{i}^{S}}+\beta \frac{d w_{i}^{U}}{w_{i}^{U}}=\frac{1}{\sigma} \frac{d M A_{i}}{M A_{i}}+\frac{(1-\alpha-\beta)}{(\sigma-1)} \frac{d S A_{i}}{S A_{i}},
\end{aligned}
$$

where we have used our choice of numeraire $\left(p_{i}^{Y}=1 / T_{i 1}^{A}\right)$ and manufacturing is assumed to be skill intensive relative to agriculture $(\alpha / \beta>\phi /(1-\phi))$.

Suppose that the country experiences an equiproportionate increase in the value of agricultural and manufacturing trade costs to all locations: $d T_{i j}^{M} / T_{i j}^{M}=d T_{i j}^{A} / T_{i j}^{A}=\gamma>0$. The increase in agricultural trade costs $\left(T_{i j}^{A}\right)$ enters directly into the agricultural zero profit condition and directly shifts the isoprice line for this sector inwards in Figure 2. For given values of production and expenditure in each location (i.e. for given values of market capacity, $m_{j}$, and supply capacity, $s_{i}$ ), the increase in manufacturing trade costs $\left(T_{i j}^{M}\right)$ reduces market and supplier access (since $\sigma>1$ in equations (22) and (23)). As a result, the manufacturing isoprice line also shifts inwards in Figure 2. Though nominal wages both fall (in terms of the numeraire), the effect of these shifts on the relative wage - and human capital accumulation - appears ambiguous. 
This analysis yields an important insight. When both manufacturing and agriculture face trade costs, the effect of increased remoteness on skill accumulation depends upon both relative skill intensity and relative trade costs. If, as in Section 3, trade costs are more important in the skill intensive sector, remote locations will experience reduced incentives to invest in skill. However, the same outcome can emerge even if ad valorem trade costs are lower in the high skill sector due to asymmetries in the affect of trade costs on agriculture and manufacturing.

First, though shipping costs may be lower for skill-intensive sectors, other trade costs, including all search, communication, and monitoring costs, are likely to be relatively high in these sectors. ${ }^{16}$

Second, a given level of ad valorem trade costs has a stronger affect on manufacturing than agriculture because input-output linkages require firms to incur trade costs on both imported intermediate imports as well as exports. Indeed, because intermediate inputs account for a substantial proportion of costs, even relatively small trade costs can become large as a proportion of value added. The relative importance of trade costs in manufacturing can be seen by noting that the change in trade costs enters once in the agricultural zero profit condition (31) but twice in the manufacturing zero profit condition (32) via its effect on both market and supplier access. $^{17}$

Third, skill-intensive manufacturing is increasing returns to scale, while low-skill agriculture is constant returns to scale. The presence of increasing returns to scale in manufacturing means that market size is important: in equilibrium, firms must sell enough units of output in order to cover the fixed costs of production. Hence, trade costs do not enter the manufacturing zero profit condition (32) directly, but instead enter through market and supplier access, which respectively weight market size and supply capacity in all of a country's trade partners by bilateral trade costs. In agriculture in contrast, the presence of constant returns to scale means that it is perunit trade costs which are important, and these enter directly into the

\footnotetext{
${ }^{16}$ New technologies (e.g. the internet) may reduce trade costs in some skill intensive sectors. One prominent example is the emergence of Bangalore as a software programming centre in India. See Leamer and Storper (2001) and Venables (2001) for further discussion of geography and new technologies.

${ }^{17}$ See Radelet and Sachs (1998) for further discussion of how trade costs which are small as a share of gross output can have very large effects on value-added.
} 
agricultural zero profit condition.

The importance of this distinction can be seen by holding a country's bilateral trade costs constant but moving production and expenditure from neighboring to distant locations. This will have no effect in the agricultural zero profit condition where only per unit trade costs matter (equation (31) where $\left.d T_{i j}^{A} / T_{i j}^{A}=0\right)$. However, reducing market and supply capacity at neighboring locations and increasing them by the same amount at distant locations (i.e. increasing a country's economic remoteness rather than its geographical remoteness) unambiguously reduces a country's market and supplier access (i.e. $d M A_{i} / M A_{i}<0$ and $d S A_{i} / S A_{i}<0$ in the manufacturing zero profit condition (32)). As above, the fall in market and supplier access reduces the relative wage and equilibrium supply of skilled workers if manufacturing is skill intensive relative to agriculture.

Finally, in the full general equilibrium of the model, changes in agricultural and manufacturing trade costs will themselves influence the distribution of production and expenditure across locations (of market capacity, $m_{j}$, and supply capacity, $\left.s_{i}\right)$, with the resulting changes in economic remoteness influencing the skill premium and incentives to invest in human capital in the way discussed above.

The importance of input-output linkages and increasing returns to scale in skill-intensive manufacturing suggests that our earlier finding that remote countries have lower incentives to invest in human capital accumulation carries over to a world where trade costs are paid on both agricultural and manufacturing goods. The analysis also suggests that reductions in trade costs in relatively skill-intensive sectors (through, for example, trade liberalization) may be particularly important in elevating human capital investments in peripheral countries.

\section{Other Determinants of Human Capital Investment}

The discussion so far has emphasized the importance of geographical location for incentives to invest in human capital. In this section, we examine the effects of changes in other parameters of the model which are related to potential determinants of human capital investment emphasized in the existing literature. To isolate the effects of these other variables, we consider the effect of parameter changes holding constant a country's mar- 
ket and supplier access. We continue to assume countries are incompletely specialized in agriculture and manufacturing (the conditions for which are derived above).

Proposition 4 The critical level of ability $a_{i}^{*}$ above which individuals become skilled is monotonically increasing and the equilibrium supply of skilled workers $S_{i}$ is monotonically decreasing in

(a) productivity in agriculture $\theta_{i}^{Y}$

(b) the cost of manufacturing production parameter $c_{i}$

(c) the cost of education parameter $h_{i}$

Proof. See Appendix.

Intuitively, increases in agricultural productivity $\theta_{i}^{Y}$ act like a rise in the price of the agricultural good. By analogy with the Stolper-Samuelson Theorem, an increase in agricultural productivity reduces the relative skilled wage, and hence reduces equilibrium human capital investments. Our theoretical framework, therefore, formalizes the idea that a productive agricultural sector or, more generally, an abundance of agricultural land and other natural resources may both hinder the development of manufacturing and impede investments in human capital (see for example the analysis of Latin America in Engerman and Sokoloff 1997 and Leamer et al 1999).

The model also captures the idea that technology and, in particular, the transfer of technology from advanced countries is important for economic development. Technology transfer that reduces manufacturing production costs, $c_{i}$, raises the maximum skilled and unskilled wage that a manufacturing firm in country $i$ can afford to pay given market and supplier access. In terms of Figure 2, the manufacturing isoprice lines shifts outwards away from the origin. Since manufacturing is skill intensive relative to agriculture, this increases the relative wage of skilled workers, and hence raises equilibrium human capital investments.

Thus, there is an important general equilibrium complementarity between technology and skills. The transfer of technology to skill intensive manufacturing industries in developing countries not only directly raises output per capita but also has positive indirect effects through induced hu- 
man capital investment. ${ }^{18}$ The incentive to transfer technology depends, in part, on a country's institutions and policy environment (see for example Acemoglu et al 2001). Hence, the analysis is consistent with an important effect of institutions on the process of economic development and with a complementarity between institutions and human capital investment.

Finally, institutions are also important via their effects on the cost of education parameter, $h_{i}$. Increases in the extent of public versus private provision of education, or changes in government regulations that reduce the private costs of education, $h_{i}$, will increase equilibrium investments in human capital. As the supply of skilled workers rises, output of the skillintensive manufacturing sector will also rise.

\section{Empirical Measurement of Market and Supplier Access}

Using bilateral trade flow data compiled by Feenstra et al (1997), we construct theoretically consistent measures of market access and supplier access for all countries at five year intervals from 1970 to 1995 using equations (22) and (23). To ensure that these measures are not driven by small countries that trade very little with the rest of the world, we restrict our sample to the 137 countries that trade with at least 5 partners.

From the trade equation $(\mathbf{T})$, the model predicts that bilateral trade flows depend upon exporting country characteristics (i.e. supply capacity, $s_{i} \equiv n_{i} p_{i}^{1-\sigma}$ ), importing partner characteristics (i.e. market capacity, $\left.m_{j} \equiv E_{j} G_{j}^{\sigma-1}\right)$, and bilateral transportation costs $\left(T_{i j}^{M}\right)$. We use country dummy variables (denoted by $d_{i}$ and $d_{j}$, respectively) to capture market and supply characteristics for each pair of countries $i$ and $j$. This has the advantage of controlling for all observed and unobserved variables that affect market and supply capacity. ${ }^{19}$ The dummy variables also capture any component of transport costs or trade policy that is common across all of a particular country's export partners and import suppliers. We model the bilateral component of transportation costs as depending upon distance $\left(\right.$ distance $\left._{i j}\right)$ and whether or not two countries share a common

\footnotetext{
${ }^{18}$ See Redding (1996) for an analysis of technology-skill complementarity within industries in advanced countries.

${ }^{19}$ In particular, the dummies capture the role of the manufacturing price index, $G_{j}$. They control, therefore, for what Anderson and Van Wincoop (2001) term 'multilateral resistance' (a country's average trade barrier with all partners).
} 
border $\left(\right.$ border $\left._{i j}\right)$. Distance is the great circle distance, in kilometers, between the two countries largest cities. Thus, the empirical counterpart of equation (21) is:

$$
\ln \left(X_{i j t}\right)=\alpha_{t}+\beta_{1 t} d_{i}+\beta_{2 t} d_{j}+\delta_{1 t} \ln \left(\text { distance }_{i j}\right)+\delta_{2 t} \text { border }_{i j}+u_{i j t} .(33)
$$

for each time period separately, where $X_{i j t}$ denotes the value of exports from $i$ to $j$ at time $t$ and $u_{i j t}$ is a stochastic error.

Table 1 presents the results of estimating this equation on the sample of non-zero trade flows, by year. The distance and common border variables have the expected sign and are statistically significant at the $1 \%$ level. The null hypothesis that the coefficients on either the country dummies or the partner dummies are equal to zero is easily rejected at conventional significance levels using a standard F-test, and the model explains over $90 \%$ of the cross-sectional variation in bilateral trade flows. The economic importance of distance appears to grow with time: whereas a $1 \%$ increase in distance is associated with a $1.2 \%$ reduction in bilateral exports in 1970 , it is associated with a $1.5 \%$ reduction in exports by 1990 .

Estimated market access $\left(\widetilde{M A}_{i t}\right)$ for exporter $i$ and supplier access $\left(\widetilde{S A}_{j t}\right)$ for importer $j$ can be constructed using coefficient estimates from equation (33) and equations (22) and (23) from Section 3.:

$$
\begin{aligned}
\widetilde{M A}_{i t} & =\sum_{j=1}^{R} d_{j}^{\widehat{\beta}_{2 t}}\left(\text { distance }_{i j}\right)^{\widehat{\delta}_{1 t}}\left(\text { border }_{i j}\right)^{\widehat{\delta}_{2 t}} \\
\widetilde{S A}_{j t} & =\sum_{i=1}^{R} d_{i}^{\widehat{\beta}_{1 t}}\left(\text { distance }_{i j}\right)^{\widehat{\delta}_{1 t}}\left(\text { border }_{i j}\right)^{\widehat{\delta}_{2 t}}
\end{aligned}
$$

Empirically, market and supplier access are highly correlated. As a result, we use $\widetilde{M A}_{i t}$ as a proxy of countries' distance from world economic activity in our empirical analysis below. Very similar results are obtained if $\widetilde{S A}$ it is used instead.

$\widetilde{M A}_{i t}$ and $\widetilde{S A}_{j t}$ have a number of advantages compared to traditional estimates of distance. Most important, they derived from a general equilibrium model of international trade that incorporates economic geography. Second, they rely upon bilateral trade data to uncover revealed access to markets and are thereby able to incorporate the effects of unobservable 
transportation costs, trade barriers, and determinants of market and supply capacity. Finally, they capture in a single measure several dimensions of physical distance.

Table 2 reports the results of regressing $\widetilde{M A}_{i t}$ on countries' great circle distance from the US, Japan and Belgium in kilometers. Distance from these three economic centers explains $90 \%$ of the variation in market access. Of the three locations, market access is most negatively correlated with distance from Brussels; coefficient estimates imply that a 1\% increase in a country's distance from that Brussels reduces market access by $0.77 \%$. Figure 3 provides a visual representation of this correlation in 1990. Notable outliers in the figure, including Canada and several Asian countries, are markets which are located near either the US or Japan.

Comparison of the distributions of market access from 1970 to 1995 indicates that peripheral countries are becoming more economically remote over time. Table 3 reports the ratios of various percentiles of these distributions at five year intervals and indicates that the distributions are characterized by increasing inequality. All three ratios $-90^{t h} / 10^{t h}, 80^{t h} / 20^{t h}$ and $75^{\text {th }} / 25^{\text {th }}$ - increase with time. This trend is interesting in its own right and worthy of further inquiry. Potential explanations include an increasingly uneven distribution of world economic activity and the rising coefficient on distance in the trade equation estimation.

\section{Empirical Relationship Between Geography and Human Capital}

In this section, we check whether the human capital implications of the model are supported by the data. Consistent with the model, we provide evidence that educational attainment is higher in countries with greater market access. Data on educational attainment for a large cross-section of developed and developing countries in 1990 is available from Barro and Lee (2001). These data record the percent of each country's over-15 population that has attained secondary and tertiary education. ${ }^{20}$ Data on both market access and educational attainment are available for approximately 100 countries, depending upon the year. More detail on the data used in

\footnotetext{
${ }^{20}$ For further information, see Barro and Lee (1993), (2001). Domenech and de la Fuente (2000) provides a complementary source of information for OECD countries.
} 
this section is provided in a data Appendix.

Table 4 reports the results of regressing higher education attainment defined as the proportion of the population who have attained secondary or tertiary education - on market access for a cross section of countries in 1990. Because the proportion of the population with higher education is bounded between 0 and 1, we employ a logistic specification:

$$
\ln \left(\frac{\text { Higher Education }}{1-\text { Higher Education }}\right)=\alpha_{0 t}+\alpha_{1 t} \ln \left(\widetilde{M A}_{i t}\right)+\varepsilon_{i t} \text {. }
$$

The first column of the table reports results of this bivariate regression for the 105 countries for which data are available in 1990. The estimated coefficient on market access is positive and statistically significant at the $1 \%$ level.

The second column of Table 4 shows that this relationship is robust to restricting attention to a smaller set of countries where we have data on additional control variables The third column of the table indicates that market access retains a significant positive relationship with higher education even in the presence of indicators thought to be important in cross country studies of development (e.g. Gallup et al 1998 and Hall and Jones 1998). The indicators, available from the Center for International Development $^{21}$, consist of a measure of the risk of expropriation by the government, the percent of countries' land that is tropical, and dummies for socialist rule and external wars. Including these variables in column (3) reduces the magnitude of the market access coefficient from 0.61 to 0.30 although it remains statistically significant at conventional critical values. Among the controls, only risk of expropriation is statistically significant: greater risk of expropriation is negatively associated with higher education attainment. $^{22}$ For comparison, the final three columns of Table 4 report similar results when OECD countries are excluded or when geographic dis-

\footnotetext{
${ }^{21}$ http://www.cid.harvard.edu/

${ }^{22}$ Similar results are obtained for various definitions of higher education (e.g. just secondary education attainment) as well as for variations on the additional control variables used (e.g. distance from the equator in place of percent of tropical land). The US, Belgium, and Japan are excluded in columns (2) to (5) to keep the sample size consistent with results reported in the last two columns. Results in earlier columns are similar if these three countries are included. All additional results, omitted to conserve space, are available from the authors upon request.
} 
tances from three centers of world economic activity are used in place of market access.

This paper provides some of the first evidence of a positive correlation between countries' human capital investments and measures of access to centers of world economic activity. Shedding further light on the mechanisms behind this correlation is an interesting area for future research. Potentially fruitful avenues for further inquiry include looking for a similar relationship across regions within countries ${ }^{23}$; analyzing the relationship between changes in educational attainment and changes in market access within countries and regions; using richer identification strategies with cross-country and cross-region data (see for example the analysis of spatial income inequality in Redding and Venables 2001); and exploiting exogenous changes in market access associated with shifts in policy regime such as trade liberalization (see for example the analysis of spatial income inequality and Mexican trade liberalization in Hanson 1996).

\section{Conclusion}

We present a model which ties a country's human capital accumulation to its distance from global economic activity. If skill intensive sectors are relatively trade-cost intensive, are characterized by stronger increasing returns to scale, or feature more pervasive input-output linkages, relatively peripheral countries will experience a lower skill premium and reduced incentives to educate their workers. Consistent with the predictions of theory, we provide empirical evidence that countries with lower market access have lower levels of educational attainment.

To the extent that human capital accumulation accelerates development, our analysis suggests that remoteness impedes income convergence with developed nations. An obvious policy implication is that peripheral countries need to get closer to the center of global economic activity. Though countries obviously cannot move, and thereby reduce their physical distance, it is possible to reduce the costs of remoteness. Perhaps most important in this regard is the need for advanced economies to lower formal

\footnotetext{
${ }^{23}$ Across countries, the model's assumption of factor immobility is relatively plausible. Within countries, peripheral regions may also be disadvantaged by the migration of skilled workers to more central regions (the 'brain drain').
} 
and informal trade barriers vis a vis the world's more isolated economies. The planned dismantling of the global Multifiber Arrangement in 2005, for example, is a step in this direction.

Also likely to be important are efforts to reduce transport costs directly via improvements in infrastructure (e.g. roads, ports, etc.) or the frequency of port calls by shipping lines. Shipping routes themselves, of course, are endogenous to economic activity, but there may be a role for developed countries to subsidize the establishment of such routes as a way of elevating opportunity on the periphery. Further evaluation of these policy options is needed to identify the relevant market failures and examine how they compare in cost-benefit terms to other policies, such as subsidizing education directly. 


\section{References}

Acemoglu, D, Johnson, S, and Robinson, J (2001) 'The Colonial Origins of Comparative Development: An Empirical Investigation', American Economic Review, 91(5), 1369-1401.

Amiti, M (2001) 'Location of Vertically Linked Industries: Agglomeration Versus Comparative Advantage', CEPR Discussion Paper, 2800.

Amiti, M and Pissarides, C (2002) 'Trade and Industrial Location with Heterogeneous Labor', CEP Discussion Paper, 541.

Anderson, J and van Wincoop, E (2001) 'Gravity with Gravitas: a Solution to the Border Puzzle', NBER Working Paper, 8079.

Barro, R and Lee, J (1993) 'International Comparisons of Educational Attainment', Journal of Monetary Economics, 32(3), 363-94.

Barro, R and Lee, J (2001) 'International Data on Educational Attainment: Updates and Implications', Oxford Economic Papers, 53(3), 541-63.

Benhabib, J and Spiegel, M (1994) 'The Role of Human Capital in Economic Development: Evidence from Aggregate Cross-country Data', Journal of Monetary Economics, 34, 143-73.

Bernard, A, Jensen, B, and Schott, P (2002) 'Falling Trade Costs, Heterogeneous Firms and Industry Dynamics', Yale School of Management, mimeograph.

Bils, M and Klenow, P (2000) 'Does Schooling Cause Growth?', American Economic Review, 90(5), 1160-83.

Davis, D (1997) 'Intra-industry Trade: A Heckscher-Ohlin-Ricardo Approach', Journal of International Economics, 39, 201-6.

Davis, D (1999) 'The Home Market, Trade, and Industrial Structure', American Economic Review, 88(5), 1264-76. 
Deardorff, A (1998) 'Determinants of Bilateral Trade: Does Gravity Work in a Neoclassical World?', Chapter 1 in (ed) Frankel, J, The Regionalization of the World Economy, NBER\& Chicago University Press.

De la Fuente, A and Domenech, R (2000) 'Human Capital in Growth Regressions: How Much Difference Does Data Quality Make?', CEPR Discussion Paper, 2466.

Eicher, T and Garcia-Penalosa, C (2001) 'Inequality and Growth: The Dual Role of Human Capital in Development', Journal of Development Economics, 66(1), 173-97.

Engerman, S and Sokoloff, K (1997) 'Factor Endowments, Institutions, and Differential Paths of Growth among New World Economies: a View from Economic Historians of the United States', in (ed) Haber, S, How Latin American Fell Behind: Essays on the Economic Histories of Brazil and Mexico, 1800-1914, Stanford University Press.

Feenstra, R, R. Lipsey, and H. Bowen, (1997) 'World Trade Flows, 19701992, with Production and Tariff Data', NBER Working Paper, 5910.

Fujita, M, Krugman, P, and Venables, A (1999) The Spatial Economy: Cities, Regions, and International Trade, MIT Press : Cambridge MA.

Gallup, J, Sachs, J, and Mellinger, A (1998) 'Geography and Economic Development', Proceedings of the World Bank Annual Conference on Development Economics, World Bank: Washington.

Galor, O and Mountford, A (2002) 'Why are One third of People Indian and Chinese: Trade, Industrialization and Demography', Brown University Working Paper, 38-01.

Hall, Robert and Chad Jones (1999) 'Why Do Some Countries Produce So Much More Output per Worker than Others?' Quarterly Journal of Economics, February, 83-116.

Hanson, G (1996) 'Localization Economies, Vertical Organization, and Trade', American Economic Review, 86(5), 1266-78.

Hanson, G (1998) 'Market Potential, Increasing Returns, and Geographic Concentration', NBER Working Paper, 6429. 
Hummels, D (1995) 'Global Income Patterns: Does Geography Play a Role?', Chapter 2 of Phd Thesis, University of Michigan.

Hummels, D (1999) 'Toward a Geography of Trade Costs', mimeograph, Purdue University.

Krugman, P (1991) 'Increasing Returns and Economic Geography', Journal of Political Economy, 99(3), 483-99.

Krugman, P and Venables, A (1990) 'Integration and the Competitiveness of the Peripheral Industry', in C. Bliss and J Braga De Macedo,(eds), Unity With Diversity in the European Economy: The Community's Southern Frontier, Cambridge University Press: Cambridge.

Krugman, P and Venables, A (1995) 'Globalisation and the Inequality of Nations', Quarterly Journal of Economics, 110(4), 857-80.

Krugman, P and Venables, A (2001) 'How Robust is the Home Market Effect?', mimeograph, London School of Economics.

Leamer, E (1997) 'Access to Western Markets and Eastern Effort', in (ed) Zecchini, S, Lessons from the Economic Transition, Central and Eastern Europe in the 1990s, Dordrecht: Kluwer Academic Publishers, 503-26.

Leamer, E, Maul, H, Rodriguez, S, and Schott, P (1999) 'Does Natural Resource Abundance Increase Latin American Income Inequality?', Journal of Development Economics, 59, 3-42.

Leamer, E and Storper, M (2001) 'The Economic Geography of the Internet Age', NBER Working Paper, 8450.

Limao, N and Venables, A (2001) 'Infrastructure, Geographical Disadvantage, Transport Costs, and Trade', World Bank Economic Review, 15, $315-43$.

Mankiw, G, Romer, D, and Weil, D (1992) 'A Contribution to the Empirics of Economic Growth', Quarterly Journal of Economics, 107(2), 407-37.

Marshall, A (1920) Principles of Economics, London: Macmillan. 
Mori, T and Turrini, A (2002) 'Skills, Agglomeration, and Segmentation', European Economic Review, Forthcoming.

Psacharopoulos, G (1994) 'Returns to Investment in Education: a Global Update', World Development, 22(9), 1325-43.

Radelet, S and Sachs, J (1998) 'Shipping Costs, Manufactured Exports, and Economic Growth', paper presented at the American Economic Association Meetings, Harvard University, mimeo.

Redding, S (1996) 'The Low-skill, Low-quality Trap: Strategic Complementarities between Human Capital and R \& D', Economic Journal, March, 458-70.

Redding, S and Venables, A (2001) 'Economic Geography and International Inequality', CEP Discussion Paper, 495, London School of Economics.

Strauss-Kahn, V (2001) 'Globalization, Agglomeration, and Wage Premia', paper presented at CEPR Erwit Conference, London, mimeograph.

Venables, A (1996) 'Equilibrium Locations of Vertically Linked Industries', International Economic Review, 37, 341-59.

Venables, A (2001) 'Geography and International Inequalities: the Impact of New Technologies', Proceedings of the World Bank Annual Conference on Development Economics, Forthcoming.

Venables, A and Limao, N (2002) 'Geographical Disadvantage: A Heckscher-Ohlin-Von Thunen Model of International Specialization', Journal of International Economics, 58(2), 239-63. 


\section{A Theory Appendix}

\section{A1. Proof of Proposition 2}

Proof. From equation (27), the zero profit condition in agriculture implies,

$$
\frac{d w_{i}^{U}}{w_{i}^{U}}=-\left(\frac{\phi}{1-\phi}\right) \frac{d w_{i}^{S}}{w_{i}^{S}}
$$

Substituting this expression into the zero profit condition in manufacturing (28), we have,

$$
\left(\alpha-\frac{\beta \phi}{1-\phi}\right) \frac{d w_{i}^{S}}{w_{i}^{S}}=-\left[\frac{1}{\sigma}+\frac{(1-\alpha-\beta)}{(\sigma-1)}\right] \gamma
$$

Note that $\quad\left(\alpha-\frac{\beta \phi}{1-\phi}\right)>0, \quad \Longleftrightarrow \quad \frac{\alpha}{\beta}>\frac{\phi}{1-\phi}$

Therefore, if $\quad \frac{\alpha}{\beta}>\frac{\phi}{1-\phi}$

$$
\frac{d w_{i}^{S}}{w_{i}^{S}}<0, \frac{d w_{i}^{U}}{w_{i}^{U}}>0, \frac{d\left(w_{i}^{S} / w_{i}^{U}\right)}{w_{i}^{S} / w_{i}^{U}}<0
$$

\section{A2. Proof of Proposition 3}

Proof. (a) follows immediately from Proposition 2 and Proposition 1 (b) follows immediately from the fact that the equilibrium number of skilled workers is negatively related to the critical level of ability $a_{i}^{*}$, while the equilibrium number of unskilled workers is positively related to $a_{i}^{*}$

$$
S_{i}=\int_{a_{i}^{*}}^{\bar{a}} \lambda(a) \bar{L}_{i} d a, \quad L_{i}=\int_{\underline{a}}^{a_{i}^{*}} \lambda(a) \bar{L}_{i} d a-\int_{a_{i}^{*}}^{\bar{a}} \frac{h_{i}}{a} \lambda(a) \bar{L}_{i} d a
$$

\section{A3. Proof of Proposition 4}

Proof. Proposition 4 is most easily proved combining Figure 2 and the results in Proposition 1. 
(a) an increase in $\theta_{i}^{Y}$ shifts the agriculture isoprice line in Figure 2 outwards. For given values of market and supplier access, which determine the position of the manufacturing isoprice line, this unambiguously reduces the relative wage of skilled workers. From Proposition 1, the fall in the relative wage of skilled workers increases $a_{i}^{*}$ and hence reduces the equilibrium supply of skilled workers $S_{i}=\int_{a_{i}^{*}}^{\bar{a}} \lambda(a) \bar{L}_{i} d a$

(b) an increase in $c_{i}$ shifts the manufacturing isoprice line in Figure 2 inwards for given values of market and supplier access. This unambiguously reduces the relative wage of skilled workers. From Proposition 1, the fall in the relative wage of skilled workers increases $a_{i}^{*}$ and hence reduces the equilibrium supply of skilled workers $S_{i}=\int_{a_{i}^{*}}^{\bar{a}} \lambda(a) \bar{L}_{i} d a$

(c) following an increase in $h_{i}$, the agriculture and manufacturing isoprice lines in Figure 2 are unchanged for given values of market and supplier access. Hence, the equilibrium relative wage of skilled workers is unchanged. For a given relative wage of skilled workers, Proposition 1 implies that an increase in $h_{i}$ increases $a_{i}^{*}$ and hence reduces the equilibrium supply of skilled workers $S_{i}=\int_{a_{i}^{*}}^{\bar{a}} \lambda(a) \bar{L}_{i} d a$.

\section{B Data Appendix}

Bilateral trade data are from Feenstra et al (1997) at five year intervals from 1970-95. To ensure that our results are not driven by small countries that trade relatively little with the rest of the world, we restrict our sample to the 137 countries that trade with at least five partners. Distance is the great circle distance, in km, between two countries' largest cities. Common border information is from the CIA World Factbook: http://www.cia.gov/cia/publications/factbook/.

Educational attainment data from Barro and Lee (2001). Higher education is defined as the proportion of the over-15 population that has attained secondary or tertiary education.

Development indicators from Gallup et al. (1998) and Hall and Jones (1998), and include: risk of expropriation by the government, the per cent of countries' land that is tropical, and dummies for socialist rule and external wars. These data can be downloaded from http://www.cid.harvard.edu.

The trade equation estimation yields measures of supply and market

capacity for all countries (the country and partner dummies). To measure 
internal distance, we use information on internal area (the average distance between two points in a circular country is: dist $\left.i i=0.66\left(\text { area }_{i} / \pi\right)^{1 / 2}\right)$ and the coefficient on internal distance is assumed to be one half of that on external distance. As shown in Redding and Venables (2001), market access measures using alternative measures of internal trade costs are highly correlated. All estimation results are robust to considering alternative measures of internal trade costs and to focusing solely on access to foreign markets. 


\begin{tabular}{|l|c|c|c|c|c|c|}
\hline Regressor & $\begin{array}{c}1970 \\
\ln \left(X_{i j}\right)\end{array}$ & $\begin{array}{c}1975 \\
\ln \left(X_{i j}\right)\end{array}$ & $\begin{array}{c}1980 \\
\ln \left(X_{i j}\right)\end{array}$ & $\begin{array}{c}1985 \\
\ln \left(X_{i j}\right)\end{array}$ & $\begin{array}{c}1990 \\
\ln \left(X_{i j}\right)\end{array}$ & $\begin{array}{c}1995 \\
\ln \left(X_{i j}\right)\end{array}$ \\
\hline $\ln \left(\right.$ distance $\left._{i j}\right)$ & -1.18 & -1.27 & -1.27 & -1.33 & -1.37 & -1.49 \\
& 0.03 & 0.03 & 0.03 & 0.03 & 0.03 & 0.03 \\
\hline $\ln \left(\right.$ border $\left._{i j}\right)$ & 0.48 & 0.41 & 0.42 & 0.31 & 0.42 & 0.44 \\
& 0.16 & 0.14 & 0.14 & 0.14 & 0.13 & 0.15 \\
\hline Country Dummies $_{\text {Observations }}$ & Yes & Yes & Yes & Yes & Yes & Yes \\
$\mathrm{R}^{2}$ & 9191 & 9936 & 9717 & 9551 & 10302 & 11182 \\
\hline
\end{tabular}

Notes: Results, by year, of regressing bilateral exports on distance and border, country and partner dummy variables. Huber-White heteroscedasticity robust standard errors note below each estimated coefficient.

Table 1: Trade Equation Estimation

\begin{tabular}{|l|c|}
\hline Regressors & Ln(Market Access) \\
\hline Ln(Distance to US) & $-0.53^{* * *}$ \\
& 8.22 \\
\hline Ln(Distance to Belgium) & $-0.77^{* * *}$ \\
& 22.40 \\
\hline Ln(Distance to Japan) & $-0.70 * * *$ \\
& 11.01 \\
\hline Observations (Countries) & 137 \\
Adjusted R-squared & 0.90 \\
\hline
\end{tabular}

Notes: Table displays OLS coefficients. T-values are listed below coefficient estimates and are based on Huber-White robust standard errors. See text for definition of Market Access (MA). ***, ** and

* signify statistical significance at the $1 \%, 5 \%$ and $10 \%$ levels.

Results on the included constant are suppressed.

Table 2: OLS Regression of Market Access on the Physical Distance of Countries from Three Economic Centers 


\begin{tabular}{|l|r|r|r|}
\hline \multirow{3}{*}{ Year } & \multicolumn{3}{|c|}{ Ratio of Market Access Percentiles } \\
\cline { 2 - 4 } & $75^{\text {th }} / 25^{\text {th }}$ & $80^{\text {th }} / 20^{\text {th }}$ & $90^{\text {th }} / 10^{\text {th }}$ \\
\hline 1970 & 2.5 & 3.4 & 6.8 \\
1975 & 2.6 & 3.5 & 7.3 \\
1980 & 2.6 & 3.7 & 7.2 \\
1985 & 2.6 & 3.8 & 7.4 \\
1990 & 2.7 & 4.2 & 8.6 \\
1995 & 2.9 & 4.2 & 10.3 \\
\hline
\end{tabular}

Notes: Table displays the ratio of various percentiles of the distribution of Foreign Market Access across countries over time. Each year contains 137 country observations.

Table 3: The Relative Distribution of Countries' Market Access Over Time, 1970 to 1990 


\begin{tabular}{|c|c|c|c|c|c|c|}
\hline Regressors & $\begin{array}{r}(1) \\
\text { Higher } \\
\text { Education } \\
\end{array}$ & $\begin{array}{r}(2) \\
\text { Higher } \\
\text { Education } \\
\end{array}$ & $\begin{array}{r}(3) \\
\text { Higher } \\
\text { Education }\end{array}$ & $\begin{array}{r}(4) \\
\text { Higher } \\
\text { Education }\end{array}$ & $\begin{array}{r}(5) \\
\text { Higher } \\
\text { Education }\end{array}$ & $\begin{array}{r}(6) \\
\text { Higher } \\
\text { Education } \\
\end{array}$ \\
\hline $\ln ($ Market Access) & $\begin{array}{l}0.66^{* * * *} \\
5.99^{*}\end{array}$ & $\begin{array}{l}0.61 * * * \\
4.32\end{array}$ & $\begin{array}{l}0.30 * * \\
2.22\end{array}$ & $\begin{array}{l}0.59 \text { ** } \\
0.27\end{array}$ & & \\
\hline Risk of Expropriation & & & $\begin{array}{c}-0.58 \text { *** } \\
4.40\end{array}$ & $\begin{array}{c}-0.41 \\
0.13\end{array}$ & & $\begin{array}{c}-0.56 \\
4.44\end{array}$ \\
\hline Percent of Land in Tropics & & & $\begin{array}{r}-0.67 \\
1.19 \\
\end{array}$ & $\begin{array}{r}-0.55 \\
0.57 \\
\end{array}$ & & $\begin{array}{r}-0.82 \\
1.42 \\
\end{array}$ \\
\hline Socialist Rule (1950-1995) & & & $\begin{array}{l}0.28 \\
0.78 \\
\end{array}$ & $\begin{array}{r}-0.01 \\
0.45 \\
\end{array}$ & & $\begin{array}{l}0.33 \\
0.94\end{array}$ \\
\hline External War (1960-1985) & & & $\begin{array}{r}-0.13 \\
0.30\end{array}$ & $\begin{array}{r}-0.14 \\
0.43\end{array}$ & & $\begin{array}{r}-0.14 \\
0.31\end{array}$ \\
\hline Ln(Distance to US) & & & & & $\begin{array}{l}-0.65 \text { *** } \\
2.85\end{array}$ & $\begin{array}{l}-0.51 \\
2.73\end{array}$ \\
\hline $\operatorname{Ln}($ Distance to Belgium) & & & & & $\begin{array}{c}-0.29 * * * \\
3.12\end{array}$ & $\begin{array}{r}-0.09 \\
0.92 \\
\end{array}$ \\
\hline Ln(Distance to Japan) & & & & & $\begin{array}{c}-0.95 * * * \\
4.59\end{array}$ & $\begin{array}{c}-0.55 * * * \\
3.28\end{array}$ \\
\hline $\begin{array}{l}\text { US, Japan and Belgium Excluded } \\
\text { OECD Excluded } \\
\text { Observations (Countries) } \\
\mathrm{R}^{2}\end{array}$ & $\begin{array}{r}\mathrm{No} \\
\mathrm{No} \\
105 \\
0.23\end{array}$ & $\begin{array}{r}\text { Yes } \\
\text { No } \\
66 \\
0.26\end{array}$ & $\begin{array}{r}\text { Yes } \\
\text { No } \\
66 \\
0.48\end{array}$ & $\begin{array}{r}\text { Yes } \\
\text { Yes } \\
49 \\
0.36\end{array}$ & $\begin{array}{r}\text { Yes } \\
\text { No } \\
66 \\
0.30\end{array}$ & $\begin{array}{r}\text { Yes } \\
\text { No } \\
66 \\
0.50\end{array}$ \\
\hline
\end{tabular}

Notes: Table displays OLS coefficients and T-values based upon Huber-White robust standard errors. Dependent variable is a logistic transformation of higher education, defined as the over 15 year old population share attaining secondary or tertiary education. The transformation is $\ln$ (Higher/(1-Higher). See text for definition of market access. Risk of Expropriation is a measure of property rights protection and varies from 1 (low) to 5 (high). Data on this measure, the percent of land in tropics, and dummies for socialist rule and external war are from the Center for International Development at Harvard (http://www.cid.harvard.edu/). Great circle geographic distance measures are in thousands of kilometers and are available from the World Bank. ***,** and * signify statistical significance at the $1 \%, 5 \%$ and $10 \%$ levels. Results on the included constant are suppressed.

Table 4: OLS Regression of Higher Education Attainment on Market Access, 1990 


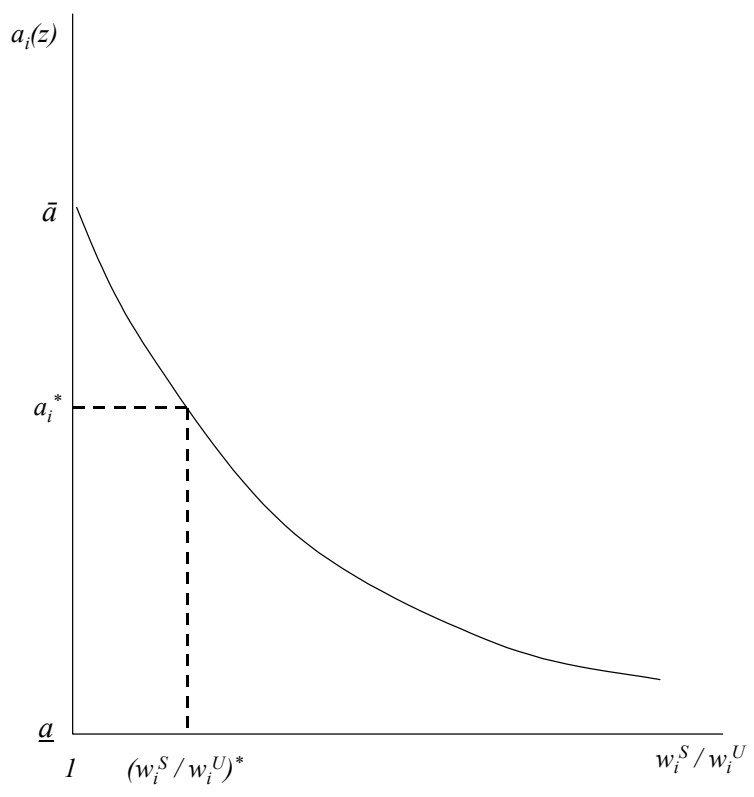

Figure 1: The relationship between the critical value of ability $a_{i}^{*}$ and the relative wage $w_{i}^{S} / w_{i}^{U}$. Only individuals with ability greater than $a_{i}^{*}$ become educated given the relative wage $\left(w_{i}^{S} / w_{i}^{U}\right)^{*}$. 


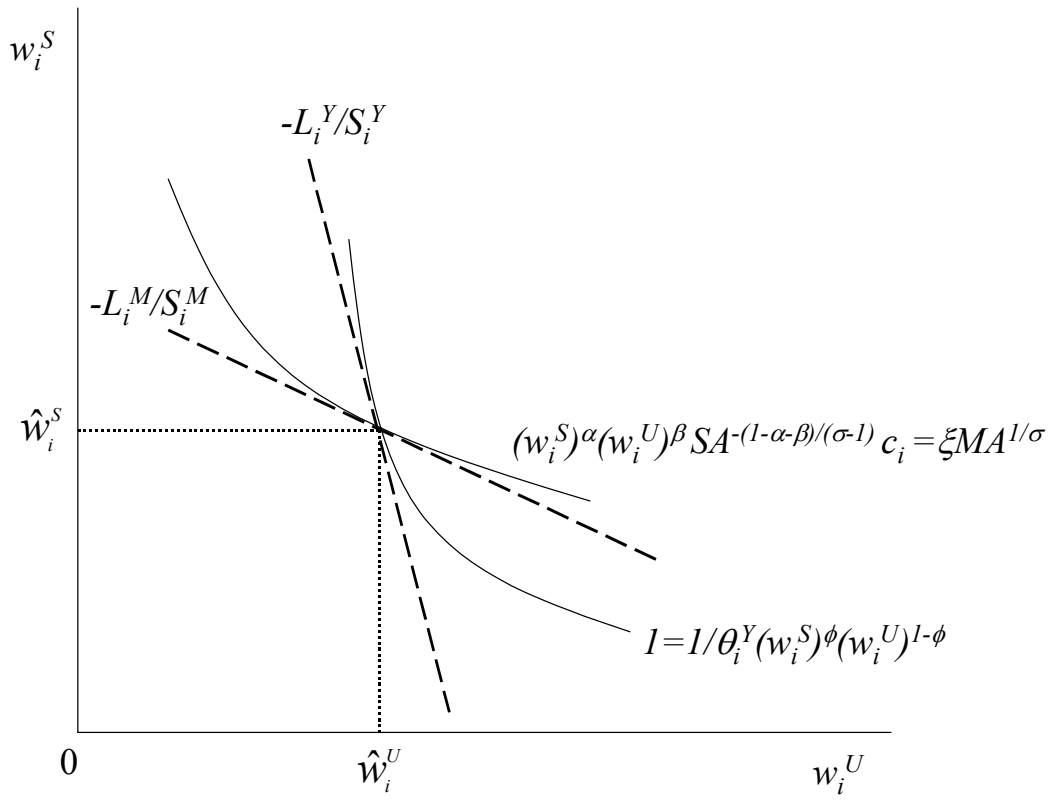

Figure 2: Equilibrium skilled wage, unskilled wage, and relative unit factor input requirements in each sector 


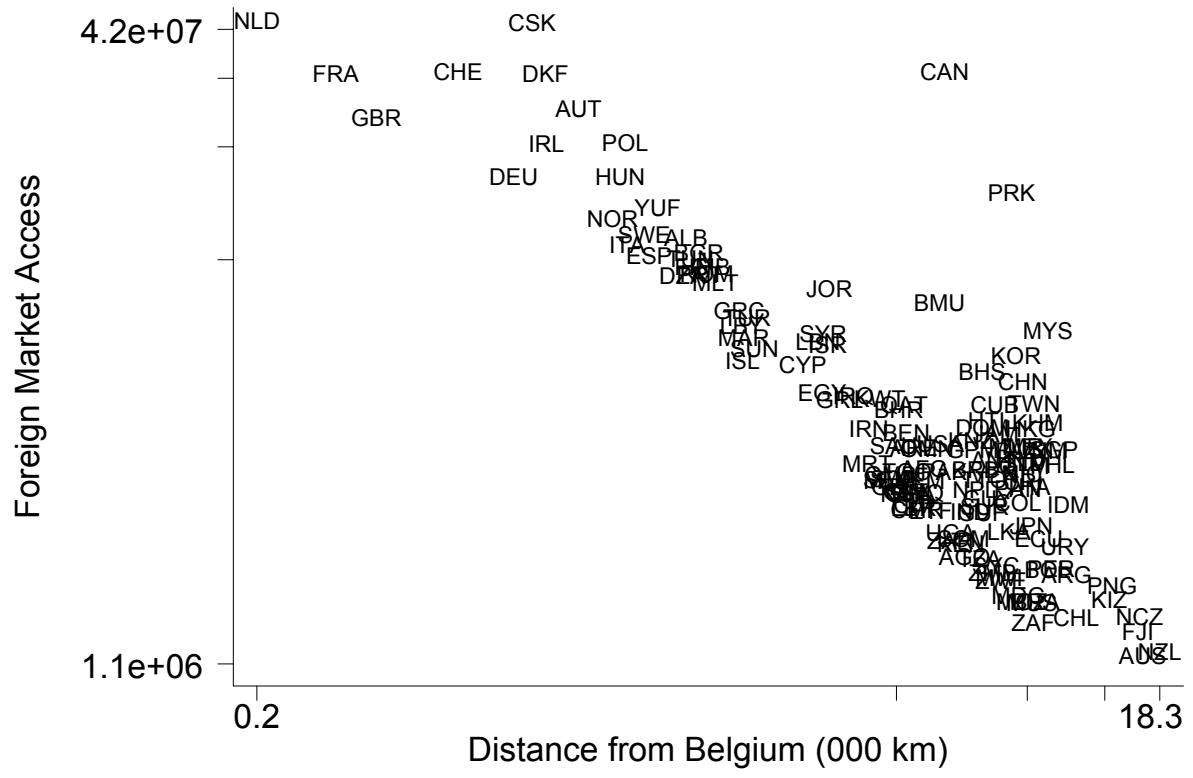

Figure 3: Foreign Market Access versus Distance to Belgium, 1990 